\title{
PELATIHAN PEMANFAATAN MEDIA ONLINE SEBAGAI SARANA PENGEMBANGAN USAHA BAGI KOMUNITAS KULINER SEHATI
}

\author{
Viola De Yusa \\ viola.d.yusa@gmail.com \\ Ana Risqa JL \\ anarisqaj1@yahoo.com
}

\section{INSTITUT INFORMATIKA DAN BISNIS DARMAJAYA}

\begin{abstract}
ABSTRAK
Tujuan dari kegiatan pengabdian masyarakat ini adalah untuk menambah dan mngembangkan pengetahuan tentang pemanfaatan media online sebagai sarana pengembangan usaha bagi komunitas Kuliner Sehati agar bisa mewujudkan ke arah yang lebih mandiri secara ekonomi dan mampu bersaing secara unggul dalam dunia usaha, maka tim memberikan materi dan pelatihan tentang pengembangan usaha melalui media online. Hasil dari pengabdian pada masyarakat yang telah dilaksanakan dengan menggunakan metode ceramah dan metode diskusi. Metode ceramah kegiatan terdiri dari penyampaian materi tentang pemasaran secara online, pemahaman terhadap media online, serta trik dan tips dalam usaha menggunakan media online seperti instagram, Facebook dan lain-lain. Metode diskusi kegiatan yang dilakukan sistem tanya jawab terhadap komunitas serta praktek dalam membuat akun Instagram untuk mempromosi usahanya. Berdasarkan hasil pengabdian, maka dapat disimpulkan bahwa dengan adanya pelatihan ini maka menjadi wadah bagi komunitas Kuliner Sehati yang ingin mengekspresikan hobby dan kecintaannya tentang semua hal berhubungan dengan makanan dan kuliner menjadi awal dari terbentuknya usaha.
\end{abstract}

Kata kunci: Pemasaran Online, Media Online, Komunitas Kuliner Sehati.

\section{PENDAHULUAN}

Kesuksesan yang dicapai suatu usaha atau bisnis bisa dilihat dari pangsa pasar yang dimiliki. Semakin luas area cakupan pemasaran produk, kesempatan untuk mendapatkan keuntungan semakin besar dan permintaan produk juga akan terus mengalir. Jika hal ini bisa tercapai, maka suatu usaha atau bisnis dapat bertahan dalam persaingan dan keberlangsungan usaha juga terjamin.
Namun, belum banyak pengelola usaha yang dapat memperluas dan mencapai pangsa pasar yang baru. Keterbatasan kemampuan dan modal yang dimiliki, serta SDM menjadi salah satu kendala yang dihadapi.

Masalah dalam pemasaran sebenarnya bisa diatasi dengan pemanfaatan media online yang ada dan saat ini banyak digunakan oleh masyarakat, misalnya media jejaring sosial, seperti Blackberry Massenger, Whatsapp, Facebook, Instagram, Twitter, Path, Olx, Tokopedia, 
Shopee, dan bahkan bisa membuat website. Kemudahan dalam pengaksesan media jejaring sosial menjadi peluang bagi pengelola usaha untuk memanfaatkanya sebagai media pemasaran baru.

Perkembangan internet saat ini adalah sangat pesat dimana hampir semua informasi akan sangat mudah diperoleh. Internet saat ini tidak hanya digunakan sebagai sumber informasi tetapi juga sebagai sarana komunikasi vital yang sangat dibutuhkan di berbagai Usaha. Bisnis melalui internet adalah salah satu trend bisnis yang berkembang saat ini. Dengan melakukan bisnis via internet (bisnis online) maka akan memperluas pangsa pasar tidak hanya ketergantungan terhadap area penjualan seperti bisnis konvensional dengan membuka lapak atau toko di suatu daerah. Pangsa pasar dari bisnis online akan jauh lebih luas karena orang-orang di seluruh indonesia bahkan di dunia dapat mengakses internet sehingga produk yang ditawarkan via internet akan jauh lebih mudah dan lebih laris.

Belum banyak pengelola suatu usaha atau bisnis yang memanfaatkan media online sebagai alat untuk memasarkan produknya agar lebih dikenali masyarakat. Dengan memanfaatkan media online sebagai media untuk memasarkan produk akan memberikan banyak manfaat. Manfaat yang didapatkan diantaranya masyarakat dapat mengetahui produk yang ditawarkan dengan mudah, bagi calon pembeli dapat melakukan perbandingan dengan produk lain sebelum melakukan transaksi pembelian, peluncuran atau promosi produk baru bisa dilakukan seefektif mungkin,meminimalkan biaya promosi, dan jangkauan pasar atau pangsa menjadi tak terbatas karena bisa diakses darimana saja dan oleh siapa saja.

Komunitas Kuliner Sehati merupakan komunitas pecinta makanan dan kumpulan dari beberapa pengusaha pemula bisnis kuliner di Provinsi Lampung yang berisikan pemuda pemudi yang memiliki kecintaan terhadap semua hal yang berhubungan dengan kuliner. Komunitas ini memiliki anggota dari kalangan generasi Mahasiswa, yang berdomisili di seputar wilayah Bandar Lampung. Komunitas Kuliner Sehati menjadi wadah bagi mereka yang ingin mengekspresikan hobi dan kecintaannya tentang semua hal berhubungan dengan makanan dan kuliner.

Sebagai salah satu komunitas yang beranggotan para pemuda dan pemudi berusia produktif tentunya komunitas Kuliner Sehati juga memiliki andil sebagai generasi penggerak perekonomian bangsa. Akan tetapi mayoritas dari anggota komunitas Kuliner Sehati masuk ke dalam pemuda pemudi kategori yang memiliki keterbatasan modal dan keahlian.

Berdasarkan uraian yang telah dijelaskan sebelumnya, perlu diadakan pengenalan cara berpromosi usaha melalui media online. Dengan diadakannya pelatihan pemanfaatan media online untuk sarana pengembangan usaha tersebut diharapkan akan mampu memberikan bekal pengetahuan yang memadai dan selanjutnya dapat diimplementasikan ke dalam usaha nyata sehingga pada akhirnya mampu membantu menyadarkan, memotivasi serta menumbuhkan ide-ide kreatif untuk dapat memanfaatkan peluang yang ada dan ikut serta dalam mewujudkan ekonomi Indonesia yang lebih kuat di masa mendatang.

Bagi kalangan usaha kuliner, menggunakan dan menjadi bagian dari komunitas dalam media online sudah menjadi kebutuhan dalam bersosialisasi terhadap usahanya. Hal ini sudah menjadi poin positif bagi usaha karena mampu menjaring pertemanan dengan banyak orang dan berusaha membangun relasi bisnis dengannya. Hal ini bisa dimanfaatkan juga untuk mengenalkan dan menawarkan produk usaha yang akan dijual. Namun, belum banyak pengusaha kuliner yang bisa 
mengelola media online-nya sebagai sarana untuk pemasaran produk, sehingga pemuda dan pemudi yang tergolong dalam komunitas Kuliner Sehati perlu diberikan pengarahan tentang cara-cara pemanfaatan media online untuk memasarkan produknya.

Berdasarkan uraian sebelumnya, dapat diidentifikasi urgensi permasalahan prioritas sebagai berikut: ketatnya persaingan usaha membuat pengelola harus mampu memanfaatkan media- media online baru sebagai alat pemasaran agar produknya bisa dikenal oleh masyarakat.

\section{METODE PELAKSANAAN}

Metode Pelaksanaa yang dilakukan dalam kegiatan pengabdian ini adalah pelatihan. Dalam pelatihan dilakukan sebagai berikut:

Pelatihan Pemanfaatan Media Online Sebagai Sarana Pengembangan Usaha dilaksanakan pada hari Rabu tanggal 09 November 2016. di lakukan di Institut Informatika Bisnis Darmajaya Lantai 2 Gedung G 1.1 beralamat di Jalan Zainal Abidin Pagar Alam No 93 Bandar Lampung.

Pelaksanaan kegiatan pengabdian masyarakat ini dilakukan dengan menggunakan metode ceramah, dan diskusi. Adapun sistematika pelaksanaan pengabdian ini adalah sebagai berikut:

Langkah 1 (Metode Ceramah)

Peserta diberikan wawasan dan motivasi mengenai pentingnya mengubah pola pikir pemasaran yang terdahulu dengan pemasaran yang modern saat ini lebih menggunakan media online, serta diberikan pemahaman tentang promosi usaha kuliner melalui media online seperti Blackberry Massanger, Whatsapp, Path, Instagram, OLX, Tokopedia, Shoppe dan masih banyak lainnya sehingga produk mereka bisa lebih dikenal orang seluruh Indonesia bahkan mancanegara bukan hanya diwilayah setempat saja meliputi materi berfikir kreatif dan inovatif ,rencana bisnis, keterampilan menjual dan bernegosiasi.

Metode ceramah materi dilakukan selama 60 menit terhadap pengenalan media online untuk pemasaran usahanya.

\section{Langkah 2 (Metode Diskusi)}

Peserta diberi fasilitas untuk melaksanakan diskusi agar dapat memanfaatkan dan mengetahui media pemasaran secara online dan cara mengoperasikan media online tersebut. Metode diskusi dilakukan selama 1 jam.

Mitra dalam pengabdian ini adalah Komunitas Kuliner Sehati merupakan komunitas pecinta kuliner dan pemula yang terjun ke usaha kuliner di Provinsi Lampung beralamat dijalan Wahidin Sudiro Husodo Pengajaran Teluk Betung Utasa Bandar lampung. Terdiri dari pemuda pemudi yang memiliki kecintaan terhadap semua hal yang berhubungan dengan kuliner. Komunitas ini memiliki anggota dari beberapa Mahasiswa yang berdomisili di seputar wilayah Bandar Lampung. Komunitas Kuliner Sehati menjadi wadah bagi mereka yang ingin mengekspresikan hobi dan kecintaannya tentang semua hal berhubungan dengan makanan dan kuliner.

\section{HASIL DAN LUARAN}

\subsection{Hasil}

Pelatihan di hadiri oleh 10 orang peserta yang merupakan anggota dari komunitas Kuliner Sehati, peserta didominasi oleh anggota komunitas yang merupakan mahasiswa dari berbagai kalangan di Bandar Lampung. Acara Pengabdian Kepada Masyarakat dengan judul "Pelatihan Pemanfaatan Media Online Sebagai Sarana Pengembangan Usaha Bagi Komunitas Kuliner Sehati". Pelatihan ini diisi dengan 2 materi. Materi pertama yaitu pengenalan pemasaran online dan materi kedua tentang 
cara mempromosikan akun Instagram untuk jualan online.

Pembahasan di materi pertama lebih dikenalkan arti dari pemasaran online, perubahan pemasaran dari tradisional ke pemasaran online, mengenalkan keinginan konsumen, tatacara memasarkan produk yang baik dan konsumen tertarik akan usaha kita. Peserta begitu antusias dengan materi yang disampaikan dan berusaha menggali potensi dan peluang yang ada disekitar mereka. Para peserta juga sangat tertarik dan memiliki rasa ingin tahu yang tinggi mengenai bagaimana media online menjadi peluang bisnis dalam berpromosi.

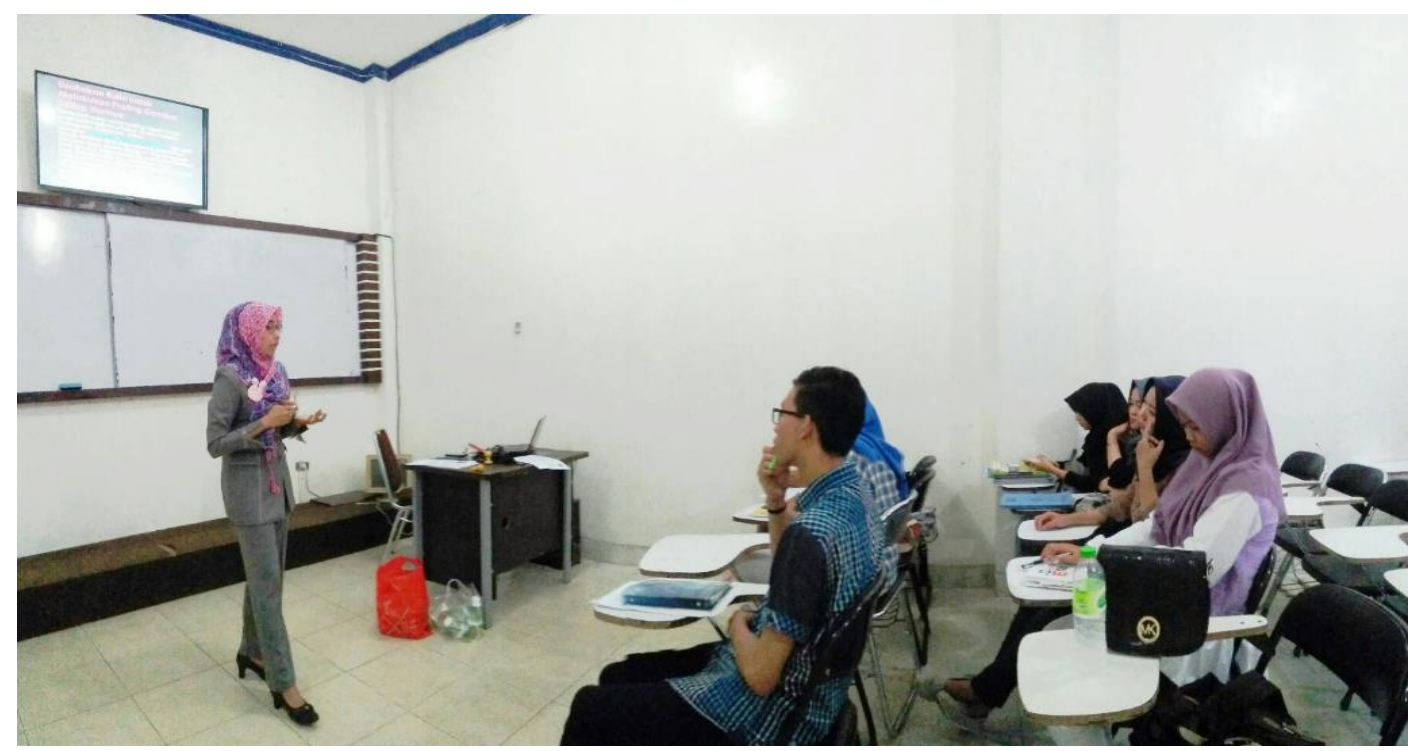

Gambar 1 Peserta Antusias Dalam Mendengar Materi

Materi selanjutnya setelah adalah tentang cara mempromosikan akun instagram anda untuk jualan online. Dalam penyampaian materi ini lebih menggali potensi peserta dalam memahami dari kegunaan media online untuk menjual suatu produk secara lebih kreatif dan inovatif. Dalam penyampaian materi ini peserta juga diharapkan dapat membedakan antara marketing dengan selling. Selain itu yang tidak kalah pentingnya adalah menerangkan dasar-dasar dalam melakukan bagian-bagian dari promosi, dan menggali potensi peserta dalam melakukan penggunaan media online yang baik dan benar serta efektif. Peserta cukup antusias dan mengajukan berbagai pertanyaan tentang cara mengoperasikan penggunaan media online dan fungsi nya.

Dalam promosi usahanya lewat media online, seorang pengusaha harus mengetahui tips dalam mengupload foto usahanya agar menarik konsumen.salah satu contoh dari media online untuk mempromosikan usaha yaitu dengan Instagram, Facebook, Twitter, website, blog. Pada era globalisasi saat ini, kebanyakan para pengusaha melakukan promosi usahanya melalui akun Instagram.

Tips cara mempromosikan akun instagram untuk jualan online sebagai berikut:

1. Pemilihan gambar dan kualitas Permulaan yang harus diterapkan jika ingin menjual produk melalui Instagram yaitu dengan Pemilihan foto atau gambar serta kualitasnya sangat mempengaruhi kesuksesan bisnis yang tengah Anda geluti tersebut. Sederhananya, semakin menarik gambar yang Anda bagikan melalui Instagram, maka hal tersebut 
akan memperoleh interaksi (like dan komentar) yang banyak dari pengguna Instagram lainnya. Itu artinya, pesan Anda untuk menjual produk tersebut telah tersampaikan dengan baik. Selanjutnya, Anda perlu meyakinkan calon konsumen melalui kalimat persuasif untuk membawanya melakukan konversi.

2. Usahakan rutin untuk melakukan posting gambar setiap harinya.

Memulai usaha agar akun Instagram tetap mempunyai aktivitas yang konsisten setiap harinya, maka Anda harus melakukan posting gambar yang baik dan kualitas yang baik. Hal ini dilakukan untuk memelihara jumlah follower.

3. Jangan abaikan kepopuleran Hastag "\#"

Mungkin kita sering kali melihat tanda "\#" atau hastag pada Instagram disertai dengan kalimat yang mewakilinya. Ya, hal tersebut bukanlah sebuah tren sesaat yang hanya digunakan untuk hiasan saja. Melainkan, hastag tersebut disertakan untuk membuat produk bisnis Anda semakin dikenal. Kategorikan semua posting Anda dengan tanda pagar (\#) di kolom keterangan (caption). Jika Anda menggunakan tren frase hashtag, maka hal tersebut dapat meningkatkan visibilitas konten Anda. Buat hashtag unik untuk bisnis Anda dan posting secara berkala. Dengan begitu, secara otomatis kategori unik memungkinkan pengguna dengan mudah menemukan foto produk bisnis Anda melalui fitur pencarian Instagram.

4. Berikan promosi khusus untuk menarik minat

Tidak ada cara terbaik untuk promosi selain dengan memberikan penawaran yang menarik untuk follower Instagram Anda. Ingatlah, follower Anda merupakan calon customer. Untuk itu, Anda sepatutnya untuk memberikan penawaran-penawaran yang membuat follower Instagram Anda merasa tertarik. Misalnya, dengan memberikan promosi khusus berupa potongan harga atau bahkan gratis untuk produk tertentu setelah memilih produk utama. Jangan lupa untuk meminta customer Anda berbagi foto produk bisnis Anda menggunakan hastag untuk memenuhi persyaratan setiap promosi itu. Mudah bukan? Hal ini bergantung pada promosi yang Anda berikan sesuai dengan keadaan bisnis Anda. Pada dasarnya, strategi ini akan menghasilkan pemasaran gratis untuk bisnis Anda.

5. Sertakan profil Instagram Anda di jejaring sosial lain

Berbeda dengan Facebook, pencarian profil dalam Instagram tidak begitu baik. Oleh sebab itulah, jika akun Anda kurang dikenal dan populer, maka tidak akan mudah untuk mendapatkan follower baru, terkecuali jika Anda tahu nama profilnya. Hal itulah yang menyebabkan akun Instagram Anda sangat sedikit proses interaksi dengan pengguna lainnya. Untuk kelemahan ini, hubungkan profil Anda secara otomatis ke Facebook, Twitter, dan Google Plus. Dengan begitu, pengikut Anda di situs tersebut dapat dengan mudah menemukan profil Instagram Anda.

Kegiatan selanjutnya adalah diskusi tentang cara menggunakan media online. Untuk mengefektifkan diskusi peserta langsung mempraktekkan dengan membuka media social online mereka seperti instagram usaha mereka. Diskusi berjalan dengan lancar dan mendapat antusias yang luar biasa dari peserta. Peserta dibimbing, diarahkan dan diberi contoh tentang pemasaran online melalui media online. 
Salah satu contoh instagram yang digunakan peserta untuk memasarkan usahanya.

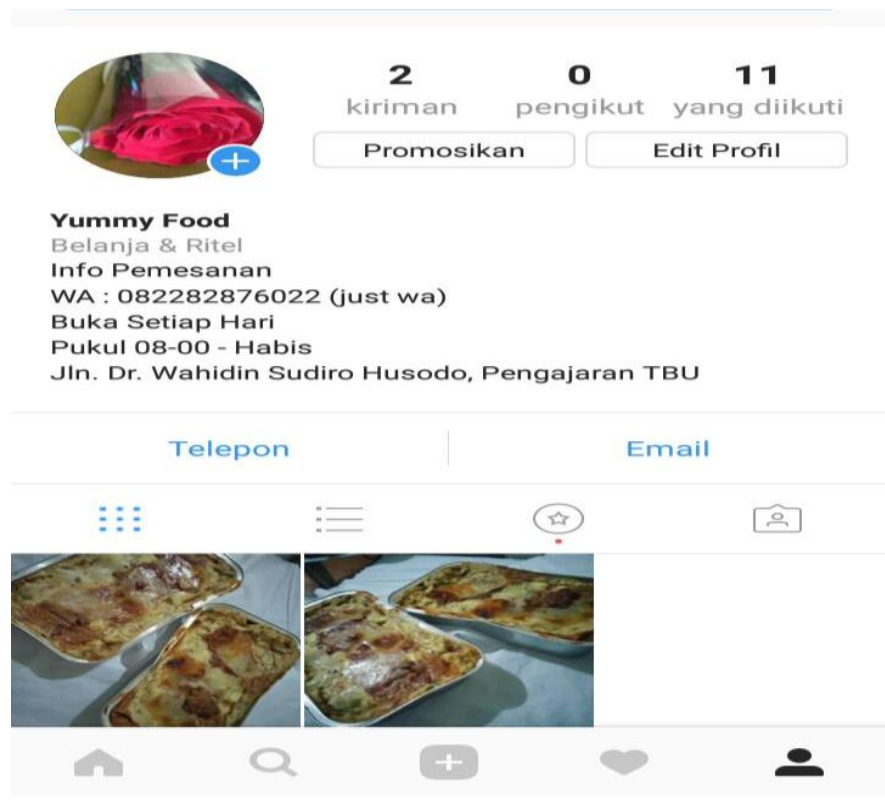

Gambar 2. Contoh Akun Instagram

\subsection{Luaran}

Berdasarkan materi yang sudah diberikan dan pelaksanaan pelatihan oleh tim kepada komunitas Kuliner Sehati di Bandar Lampung, maka dapat dijelaskan sebagai berikut:

a. Maksud dan tujuan dari pengabdian pada masyarakat sudah tercapai.

b. Permasalahan-permasalahan yang dihadapi oleh komunitas Kuliner Sehati sudah terpecahkan dan sudah ada solusinya, yaitu mitra sudah diberikan materi dan pelatihan sesuai dengan permasalahan yang dihadapi yaitu materi pemasaran online dan materi tentang cara mempromosikan akun instagram anda untuk jualan online

c. Kegiatan pengabdian pada masyarakat sudah dilaksananakan pada mitra sesuai dengan jadual yang sudah disepakati.

d. Komunitas Kuliner Sehati sudah melakukan praktek pembuatan akun instagram dan cara mempromosikannya.

\section{KESIMPULAN}

Dari kegiatan pengabdian kepada masyarakat ini dapat disimpulkan bahwa:

1. Kegiatan pengenalan pemanfaatan pemasaran online melalui media online ini dilakukan dengan metode ceramah berupa motivasi, pemberian pemahaman tentang ketrampilan menjual dalam menggunakan media online.

2. Para peserta komunitas Kuliner Sehati merupakan komunitas pecinta makanan dan kumpulan dari beberapa pengusaha pemula bisnis kuliner di Provinsi Lampung yang berisikan pemuda pemudi yang memiliki kecintaan terhadap semua hal yang berhubungan dengan kuliner. Komunitas ini memiliki anggota dari kalangan generasi Mahasiswa, yang berdomisili di seputar wilayah Lampung. Komunitas Kuliner Sehati menjadi wadah bagi mereka yang ingin mengekspresikan hobby dan 
kecintaannya tentang semua hal berhubungan dengan makanan dan kuliner. Sehingga diperlukan suatu pelatihan yang lebih mendalam untuk meningkatkan peran aktif komunitas Kuliner Sehati dalam ikut serta mengatasi masalah-masalah yang muncul dalam dunia usaha. Pelatihan yang dapat diselenggarakan misalnya pelatihan tentang pengelolaan media sosial, dan lain-lain yang berkaitan dengan promosi usaha. Sehingga akan semakin memaksimalkan pengelolaan suatu usaha dan dapat bersaing dalam menghadapi pasar global.

\section{DAFTAR PUSTAKA}

Dewi.Ika Novita, dkk. 2014. Pelatihan Pemanfaatan Media Online Sebagai Sarana Pemasaran Online Untuk Membangun dan Menupuk Jiwa Kewirausahaan Bagi UKM BAI. Semarang; Universitas Dian Nuswantoro

Hendro. 2011. Dasar-dasar Kewirausahaan. Jakarta : Erlangga.

Kotler,P., K.L. Keller .2009. Manajemen Pemasaran Edisi Ketiga Belas Jilid 2. Jakarta : Erlangga

Mahendra.I Gede, dkk. 2014. Pelatihan Pembuatan Blog Sebagai Media Promosi dan Bisnis Internet Di Era Global Bagi Guru-Guru SMA Di Kecamatan Nusa Penida, Klungkung. Bali ; Universitas Pendidikan Ganesha 